\title{
Sprouting employability skills in building technology students' using cooperative learning approaches in Nigerian Polytechnics
}

\author{
Jane Itohan Oviawe $^{1^{*}}$, Agnes Omokhekpe Anetekhai ${ }^{2}$ \\ ${ }^{1}$ Department of Vocational and Technical Education, Ambrose Alli University, \\ Ekpoma, Edo State, Nigeria. \\ ${ }^{2}$ Federal Polytechnic, Auchi, Edo State, Nigeria \\ *Corresponding email: janeoviawe@aauekpoma.edu.ng
}

Published: 30 April 2020

To cite this article (APA): Oviawe, J. I., \& Anetekhai, A. O. (2020). Sprouting employability skills in building technology students' using cooperative learning approaches in Nigerian Polytechnics. Asian Journal of Assessment in Teaching and Learning, 10(1), 59-68. https://doi.org/10.37134/ajatel.vol10.1.7.2020

To link to this article: https://doi.org/10.37134/ajatel.vol10.1.7.2020

\begin{abstract}
This study investigated the areas of cooperative learning approaches for sprouting employability in polytechnic building technology students' in Nigeria for the expertise of practice upon graduating from school using descriptive survey research design. Two research questions and four null hypotheses guided the study. The population for the study consisted of 99 building technology lecturers that offer building technology programmes in Federal, State and Private Polytechnics in South-East and South-South Nigeria. Since the population was not too large, there was no sampling. The instrument used for data collection was a 36-item questionnaire derived from the literature reviewed. Five experts validated the instrument. Cronbach alpha reliability method was used to determine the reliability of the instrument and a reliability coefficient of 0.87 was obtained. The research questions were answered using Mean statistic, while the null hypotheses were tested using Analysis of Variance (ANOVA) and z-test at .05 level of significance. The findings revealed among others that lecturers utilize all the aspects of cooperative learning approaches; and that all the employability skills required by building technology students/graduates can be developed using cooperative learning approaches. Based on the findings of this study, it was recommended among others that assessment of building technology students should be all-encompassing to include the development and mastery of employability skills for functionality in the ever dynamic and global workplace.
\end{abstract}

Keywords: Employability Skills. Building Technology, Cooperative Learning Approaches, Polytechnics

\section{INTRODUCTION}

Polytechnics in Nigeria are expected to produce trained middle-level workforce to drive her economy; produce technologists who would use their technical skills to work in industries or go to the universities to acquire more sophisticated skills in their chosen careers. The graduates of polytechnics are to take up a career in the fields of manufacturing, commerce, science, technology, applied social science and applied arts (NBTE, 2008). Polytechnic education is an incubator for hatching saleable skills and nurturing vocational competence of its recipients. According to the Federal Republic of Nigeria (2014), polytechnic education is a lifelong educational system which provides opportunities for people to continue to grow and develop and update their skills and competencies. One of the programmes offered in the polytechnic is Building technology.

Building technology is one of the programme offered in higher institutions of learning. It is concerned with the extensive technological skills which go hand in hand with the capacity to manage people, tools, machines and products to carry out building construction tasks professionally and successfully. It is aimed at producing technicians who will be able to perform basic functions in Building Technology practice, both in the private and public sector NBTE (2008). The objectives of the ND 
programme are to produce diploma holders that will assist the professional builders in the areas of (i) production of simple buildings; (ii) maintenance of simple buildings; (iii) management of small projects; (iv) costing of simple construction work; (v) cost control techniques in minor construction and engineering works; and (vi) selection of materials and technicians for new building systems (NBTE, 2007). These objectives properly fit into section (1) number (7d) of the national policy on education, which emphasizes the acquisition of appropriate skills and the development of mental, physical and social abilities and competencies as equipment for the individual to live in and contribute to the development of the society (Federal Republic of Nigeria, 2014). The realization of these goals principally depends on the quality of graduates and their awareness of societal and workplace demands for future impacts in the face of technological development.

Every building technology graduates are expected to be able to secure employment, set up an independent venture or pursue further education in building construction career. Oviawe and Uwameiye (2020) asserted that employers globally require staff highly trained workforce with generic, technical and academic skills to meet the demands of the dynamic changes in technology, increase in social and global competition. Employers of all kinds require their workforce to work readily and confidently across the worldwide operation, using a global outlook to consider new opportunities and challenges. Building Technology graduates are expected by employers of labour, construction contractors, educators, politicians and the world of work to possess flexible employability skills over necessary skills. However, the result of the training offered to learners while in school fails to match up with the expectations of the world of work thereby leaving the graduates short of the employability skills (broad set of knowledge, work habits, character traits) perceived to be essential in the ever dynamic workplace. Employers of all kinds require their workforce to work readily and confidently across the worldwide operation, using a global outlook to consider new opportunities and challenges (Oviawe \& Uwameiye, 2020). Professor Charles Soludo lamented that Nigerians are not employable due to a poor standard of education (Ajuluchukwu, 2012). Ajuluchukwu reported that about $60 \%$ of graduates being produced from the Nigerian tertiary institutions were not qualified for employment at the global level.

Buttressing this, the National Bureau of Statistics (2018) asserted that unemployment and underemployment are on the increase in Nigeria, with $25.50 \%$ of her youths unemployed as at the third quarter of $2017 ; 52.5 \%$ in the third quarter of 2017 ; which increased to $30.50 \%$ in the second quarter of 2018; and 55.4\% in the third quarter of 2018. Similarly, Senator Chris Ngige, the current Minister of Labour and Employment while declaring open a workshop on "Breaking the Resilience of High Unemployment rate in the Counter" held in Abuja the nation's capital posited that the incessant increase of unemployment in Nigeria was alarming and added that it is projected to reach $33.5 \%$ by 2020 (Premium Times, 2019).

To this end, Schleicher (2012) reported that on the part of the students, there seems to be lack of awareness of these saleable skills and it is attributed to the fact that employability skills are neither taught explicitly nor assessed over factual retention. Consequently, the students are left to pick up employability skills by chance without a conscious design of the school system to inculcate these skills. Hence, the teachers' choice of instructional delivery strategies has favoured teacher-centred over learners-centred approaches and without a model to enhance problem-based, project-based, community engagement and cooperative strategies of learning which are much advocated for the actualization of employability skills inculcation in the students. It is against this background of failure to meet the need of equipping building technology graduates with the essential employability skills required in the ever dynamic world of work that this study is conducted to integrate cooperative learning model in building technology classrooms to facilitate the development of employability skills in students'.

The purpose of this study was to investigate areas of cooperative learning approaches for sprouting employability skills in building technology polytechnic students' in South-East and South-South geopolitical zones of Nigeria. Specifically, this study sought to identify the cooperative learning approaches used by polytechnic lecturers in building instructional technology delivery; and employability skills that can be developed in building technology students' utilizing cooperative learning approaches.

\section{LITERATURE REVIEW}

Developments in technology have significant effects on the teaching and learning of building technology. To this end, Kaufman (2013) posited that technology creates a vital pressure for change. This is, changing 
both what we need to know and how we come to know it. Some of the developments in building technology are the movement from paper and pencil drafting to Automated Computer Aided Designs (AutoCAD); carton, wood and glue modelling to Building Information Modelling (BIM); structural and sectional detailing to structural analysis with software among others. Expertise to solve problems using technology is thus a core requirement of the generic skills, hence information and communication technology (ICT).

Similarly, Larson and Miller in Kaufman (2013) argued that of great importance is for students to be able to research, organize, evaluate and communicate information with technology. The need for technology therefore transcends 'playing with gadgets' (Larson, Miller \& Ribble, 2010) to include personal responsibility, personal productivity, adaptability, creativity, collaboration and communication. It is worth noting that knowledge and information in this era of technology also transcend individuals. Therefore, the availability and accessibility of the Internet allows every building technology student to reach out beyond the class boundaries and contribute to the body of knowledge thereby overriding students' passiveness. In the face of individual contributions towards the actualization of a given task/building project, the importance of collaborative intelligence is attained, which in turn enhances collective learning. Hence, the employability skills of individualized knowledge creation, teamwork, team management, team spirit, etc with the wider community of learners can only be developed through cooperation and are sustained with clarity of its model.

Cooperation focuses on bringing two or more individuals together to learn towards completing a given task. It could be in many forms: face-to-face, computer-mediated (Computer Supported Cooperative Learning (CSCL), joint or labour divided, synchronous or asynchronous etc. Each type of cooperative learning is simply a mutual engagement of participants in a coordinated effort to solve a problem together (Lai, 2011). According to Dillenbourg in Oviawe, Ezeji and Uwameiye (2016), cooperative learning involves activities such as reading, building, predicting, and mechanisms which include induction, deduction, and compilation. The by and significant product of cooperative learning is an integrated ability of individuals to reflect on the same task. Using the variance abilities and skills of persons in their best dispositions to achieve a common goal underpins cooperatives intelligence.

In contrast, the extent to which these persons learn from each other on the delivery processes of the given task further highlights cooperative learning. Collaborative intelligence according to Markova and McArthur (2016), has the capacity of a person to think with others towards accomplishing a unique project that matters to people in the group. However, collaborative learning and collaborative intelligence could be further detailed leaning on dynamic learning capacity.

The concept of dynamic learning capacity is the capacity of an organization to create purposefully, extend or modify its knowledge base through reconfiguring learning routines that explore, retain and exploit knowledge inside and outside organizational boundaries (Manley \& Chen, 2015). Furthermore, integrating internal and external knowledge in dynamic learning capability require that opportunities for knowledge exploration, transformation, and exploitation are created and underpinned. To this end, Manley and Chen (2015) posited that knowledge exploration emphasizes individual identification of valuable new knowledge from external sources and thus combines with internally generated ideas derived from existing learning routines, from selecting thoughts through discussion, analysis and debate. Lewin, Peter and Massini (2011) asserted that exploratory learning occurs when organizational members identify, acquire, analyze and process new knowledge, which is crucial for business operations. The indispensable team skills of sharing explored information, ascertaining open communication, building relationship and achieving mutual understanding of the given task are realizable in cooperative adventures (Alashwal \& Abdul-Rahman, 2014). Besides, Manley and Chen (2015); Lewin, Peter and Massini (2011) posited that knowledge exploitation entails the applicability and integration of newly assimilated knowledge to reshape the outcome and satisfy emerging needs in projects/buildings while knowledge transformation balances the external and internal knowledge intake, hence linking exploratory and exploitation learning.

Manley and Chen (2015) adopted the opportunities for knowledge exploration, knowledge transformation, and knowledge exploitation to create a circular model of dynamic learning which was refined to cooperative learning approaches. This model depicts that improvement in exploratory learning, improves transformative learning which also improves exploitative learning; exploitative learning effectively readjusts operating routines (how things are done). These improvements cumulatively impact on performance outcomes, positive outcome invariably motivates to renew exploratory learning (Manley $\&$ Chen, 2015). Although the Manley's cooperative learning model focused on infrastructure construction 
organizational project life cycle, the learning model could be adopted in building technology classrooms to enhance the advancement of employability skills in the students. A model is a representation, usually based on analogies, which are made contextualizing certain portions of a domain with a given goal. The representation according to Chamizo (2013) could be essential ideas, phenomenon or object generated by a person or group of people; analogy depicts similarity of properties or features in a model while specific goals are the purpose for which the model is proposed or designed. Chamizo (2013) added that the purpose of the model is derived from the manipulation of its features to enable the learning of how and why it is first created. Cooperative learning here represents the prototypical flow of knowledge into the classroom environment from both the teacher and learners beyond the boundaries of the classroom environment. Cooperative learning in building technology proposes a learning approach that allows learners the opportunity to create, extend or modify their knowledge base through reconfiguring learning routines that explore, retain and exploit knowledge inside and outside the school coverage. The purpose would be to make the learners active and creators of their own knowledge; use the developments within their environment thereby making an artefact creator out of every learner; and ultimately transform the approaches to tasks/projects, as a result improve the outcome of the individual and his/her product.

The integration of cooperative learning in teaching and learning building technology will alter the approach to instructional delivery on-going. By instructional delivery practices, one refers to the course of action in which a teacher personalizes instructional approaches as it suits his/her expectations, learners, schools and workplace demands. It is a process by which teachers apply a repertoire of instructional strategies to communicate and interact with students around academic content, and to support students' engagement (California Community Colleges, n.d). Varieties and differentiation in instructional delivery practice afford the teachers opportunities to make teaching and learning relevant to actual-life issues which directly allow learners to explore, inquire, and create knowledge. The explorative, transformative and exploitative areas of cooperative learning when utilized in a classroom environment will open up learners active participation, build on existing knowledge and skill, enhance creativity and imaginative skills, evaluate individual performances, integrate technological approaches, build effective teamwork and communication skills. All these are aspects of employability skills required in the global workplace.

The need to inculcate employability skills into school graduates to meet the needs and demands of the dynamic workplace has remained a quest for a possible solution in recent times. Employability skills are a broad set of knowledge, skills, work habits and character traits that are perceived by all stakeholders (teachers, school reformers, employers of labour and the society) to be essential to the success in the present-day workplaces, particularly in collegiate programmes, contemporary careers. Employability skills include: critical thinking and problem-solving skills; communicative skills, information and media literacy skills, contextual learning skills, learning and innovation skills; cooperation/collaboration, research and information fluency; digital citizenship, technology operations and concepts (Great School Partners, 2016). Kaufman (2013) posited amidst the variations and discrepancies concerning the definitions of employability skills and what constitutes these skills, the focus is entirely on what students could do with knowledge and their effectiveness in authentic contexts. Similarly, Lai (2011) asserted that the much desired critical thinking, innovative and creative skills, technology friendliness etc, communication and collaboration skills are much desired; especially in building technology whose products/graduates are expected to work amidst team members as no one individual carries out a building project. The affordances of cooperative learning are a physically powerful force for employability skills which are essential for adaptability and development in the world of work. It is against this background that this study sought to identify the areas of cooperative learning for sprouting employability skills in building technology students.

\section{RESEARCH METHOD}

The study adopted the descriptive survey research design investigate the areas of cooperative learning approaches for sprouting employability skills in building technology graduates in 11 States that make up the South-East and South-South geo-political zones of Nigeria.

\section{Study Participants}

As shown in Tables 1 and 2, the study participants comprised of 99 lecturers from NBTE accredited 
Federal, States and Private Polytechnics in South-East and South-South geo-political zones of Nigeria. The South-East geo-political zone is made up of five States, namely: Abia, Anambra, Ebonyi, Enugu and Imo; while the South-South region consists of six States, namely: Edo, Delta, Akwa-Ibom, Bayelsa, Cross River and Rivers. which were chosen for the study due to the location of the authors' institutions. The researchers of the study did not employ any sampling procedure since the population of building technology lecturers in polytechnics were few; hence the entire population was covered in the study.

Table 1: List of NBTE accredited Polytechnics offering Building Technology in South-East and South-South Nigeria

\begin{tabular}{|c|l|l|}
\hline S/No. & \multicolumn{1}{|c|}{ South-East } & \multicolumn{1}{c|}{ South-South } \\
\hline 1 & Abia State Polytechnic & Auchi Polytechnic, Auchi \\
\hline 2 & $\begin{array}{l}\text { Akwa-Ibom State Polytechnic, Ikot-Osurua } \\
\text { State }\end{array}$ & Heritage Polytechnic, Ikot Udota, Akwa-Ibom \\
\hline 3 & Federal Polytechnic, Oko, Anambra State & Delta State Polytechnic, Ozoro \\
\hline 4 & $\begin{array}{l}\text { Akanu Ibiam Federal polytechnic, Unwana, } \\
\text { Ebonyi State }\end{array}$ & $\begin{array}{l}\text { National Institute of Construction Technology, } \\
\text { Uromi, Edo State }\end{array}$ \\
\hline 5 & $\begin{array}{l}\text { Institute of Management and Technology, } \\
\text { Enugu State }\end{array}$ & \\
\hline 6 & Federal Polytechnic, Nekede, Imo State & \\
\hline
\end{tabular}

Table 2: Demographic Data of Participants in South-East and South-South Nigerian Polytechnics based on Institution Ownership

\begin{tabular}{|c|l|c|}
\hline S/No. & \multicolumn{1}{|c|}{ Institutions } & No. of Lecturers \\
\hline A. Federal Polytechnics & 15 \\
\hline 1 & Auchi Polytechnic, Auchi & 12 \\
\hline 2 & Federal Polytechnic, Oko, Anambra State. & 10 \\
\hline 3 & Federal Ploytechnic, Nekede, Imo State. & 10 \\
\hline 4 & Akanu Ibiam Federal polytechnic, Unwana, Ebonyi State. & 9 \\
\hline 5 & National Institute of Construction Technology, Uromi, Edo State. & $\mathbf{5 6}$ \\
\hline \multicolumn{2}{|l|}{ Sub-total } & 8 \\
\hline B. State Polytechnics & 9 \\
\hline 1 & Abia State Polytechnic. & 11 \\
\hline 2 & Akwa-Ibom State Polytechnic, Ikot-Osurua. & 10 \\
\hline 3 & Delta State Polytechnic, Ozoro. & $\mathbf{3 8}$ \\
\hline 4 & Institute of Management and Technology, Enugu State. & \\
\hline \multicolumn{2}{|l}{ Sub-total } & $\mathbf{9 9}$ \\
\hline C. Private Polytechnics & \\
\hline 1 & Heritage Polytechnic, Ikot Udota, Akwa-Ibom State. & \\
\hline Total & \multicolumn{2}{|c|}{} \\
\hline
\end{tabular}

\section{Research Instrument}

The instrument used for data collection in this study was a questionnaire developed by the researchers from the literature reviewed. The questionnaire had two sections; section A collected data on the respondents with regards institution type and ownership; while section B addressed the research questions consisting of 36 items, where 15-items measure the cooperative learning approaches used in building technology instructional delivery practices in Nigeria, 21-items measure employability skills that can be developed in building technology graduates utilizing cooperative learning with a five-point Likert type scale; research question 1 had - Very Highly Utilized (VHU)- 5, Highly Utilized (HU) -4, Often Utilized -3 , Seldomly Utilized -2, and Not Utilized (NU) - 1; while research question 2 had responses of: Strongly Agree (SA) - 5, Agree (A) - 4, Undecided -3, Disagree (D)-2, and Strongly Disagree -1.

\section{Instrument Validity and Reliability}

The instrument was face validated by five experts from building technology departments in Universities 
Sprouting employability skills in building technology students' using cooperative learning approaches in Nigerian Polytechnics

and Polytechnics from tertiary institutions in South-East and South-South Nigeria. Cronbach Alpha method was used to establish the internal consistency of the items in the instrument. The reliability index of 0.87 was obtained.

The instrument was administered by the researcher and five other research assistants. The questionnaires were administered with the help of five research assistants. Out of the 99 copies of the questionnaire that were administered, 86 were duly completed and returned after two weeks. This gave an $86 \%$ return rate.

\section{Data Collection and Analyzes}

A Mean statistic was used to answer the research questions while One-way Analysis of Variance (ANOVA) and z-test was used to test the null hypotheses at .05 level of significance. The decision rule was based on a mean benchmark of 3.00; such that the mean response of 3.00 and above was taken as utilized or agreed, while the items with a mean value below 3.00 were regarded as not utilized or disagreed. For the null hypotheses, where the calculated F or z-calculated is more significant higher than the table value at 0.05 level of significance, reject the hypotheses. If otherwise, the hypotheses were retained.

\section{RESULTS AND DISCUSSION}

In response to research question 1, 'What are the cooperative learning approaches used in building technology instructional delivery practices?', where Table 3 reveals that all the 15 items had their mean rating ranging from 4.00 to 4.22 , which are above the criterion mean of 3.00 showing that all the items listed are features of cooperative learning models utilized in building technology instructional delivery.

Table 3: Mean ratings of Lecturers on the Cooperative Learning Approaches used in Building Technology instructional delivery practices

\begin{tabular}{|c|c|c|c|}
\hline $\mathbf{S} / \mathbf{N}$. & Cooperative Learning Approaches & $\overline{\mathbf{X}}$ & Remarks \\
\hline \multicolumn{4}{|c|}{ A. Exploratory Learning } \\
\hline 1 & Use guided inquiry in delivery building technology instruction. & 4.22 & Utilized \\
\hline 2 & Encourage individualized articulation in building technology classes. & 4.15 & Utilized \\
\hline 3 & Apply peer-to-peer learning in delivery building technology instruction. & 4.22 & Utilized \\
\hline 4 & Make use of cooperative learning in delivery building technology instruction. & 4.17 & Utilized \\
\hline \multirow[t]{2}{*}{5} & Carry each learner along through active and participatory learning. & 4.20 & Utilized \\
\hline & Mean of means & 4.19 & \\
\hline \multicolumn{4}{|c|}{ B. Transformative Learning } \\
\hline 6 & Organize real-life project workshops within the class. & 4.24 & Utilized \\
\hline 7 & Conduct problem-based discussions/debates. & 4.22 & Utilized \\
\hline 8 & $\begin{array}{l}\text { Make sure that learners do systematic reporting as a means of } \\
\text { evaluation/feedback. }\end{array}$ & 4.24 & Utilized \\
\hline 9 & Take learners on work-visits as a routine to learning best workplace practices. & 4.00 & Utilized \\
\hline \multirow[t]{2}{*}{10} & Organize micro-exhibitions for learners to showcase their ingenuity. & 4.01 & Utilized \\
\hline & Mean of Means & 4.14 & \\
\hline \multicolumn{4}{|c|}{ C. Exploitative Learning } \\
\hline 11 & Test learners' knowledge using project-based learning. & 4.02 & Utilized \\
\hline 12 & Teach/create new concepts through design-based learning. & 4.01 & Utilized \\
\hline 13 & Develop learners' ability through problem-based learning. & 4.03 & Utilized \\
\hline 14 & Support students' to learn through programmed instructions. & 4.00 & Utilized \\
\hline \multirow[t]{2}{*}{15} & Instruct learners' responsibility using independent learning approach. & 4.00 & Utilized \\
\hline & Mean of Means & 4.01 & \\
\hline
\end{tabular}

In response to research question 2, 'What are the employability skills that can be developed in building technology graduates utilizing cooperative learning?', where Table 4 reveals that all the items were rated by the respondents as strongly agreed to indicate that these items are employability skills that could be developed in building technology students' using cooperative learning approaches. 
Table 4: Mean ratings of Lecturers on the Employability Skills that can be developed in Building Technology Students

\begin{tabular}{|c|l|c|c|}
\hline S/N. & \multicolumn{1}{|c|}{ Employment Skills } & $\overline{\mathbf{X}}$ & Remarks \\
\hline 1 & Critical thinking & 3.99 & Strongly Agreed \\
\hline 2 & Problem-solving & 3.99 & Strongly Agreed \\
\hline 3 & Creativity & 3.94 & Strongly Agreed \\
\hline 4 & Imaginative & 3.98 & Strongly Agreed \\
\hline 5 & Teamwork & 3.97 & Strongly Agreed \\
\hline 6 & Leadership & 3.66 & Strongly Agreed \\
\hline 7 & Communication & 4.00 & Strongly Agreed \\
\hline 8 & Information fluency & 4.01 & Strongly Agreed \\
\hline 9 & Research & 4.02 & Strongly Agreed \\
\hline 10 & Media literacy & 4.00 & Strongly Agreed \\
\hline 11 & Technological literacy & 4.01 & Strongly Agreed \\
\hline 12 & Contextual learning & 4.00 & Strongly Agreed \\
\hline 13 & Innovative & 4.03 & Strongly Agreed \\
\hline 14 & Adaptability & 4.00 & Strongly Agreed \\
\hline 15 & Flexibility & 4.00 & Strongly Agreed \\
\hline 16 & Personal productivity & 3.98 & Strongly Agreed \\
\hline 17 & Responsibility & 4.00 & Strongly Agreed \\
\hline 18 & Analytical & 3.99 & Strongly Agreed \\
\hline 19 & Evaluative & 3.94 & Strongly Agreed \\
\hline 20 & Environmental literacy & 3.97 & Strongly Agreed \\
\hline 21 & Entrepreneurial literacy & 4.00 & Strongly Agreed \\
\hline & Mean of Means & $\mathbf{3 . 9 7}$ & \\
\hline
\end{tabular}

The result in Table 5 revealed F-calculated value of 1.007 while F-critical is 3.11 with 2 and 83 degrees of freedom at .05 level of significance. Therefore, the null hypothesis is retained. This implies that Building Technology lectures in Federal, State and Private Polytechnics in South-East and South-South Nigeria rated these aspects of cooperative learning approaches as being utilized for building technology instructional delivery.

Table 5: Summary of Analysis of Variance on the responses of lecturers on the aspects cooperative learning model used in building technology instructional delivery

\begin{tabular}{|c|c|c|c|c|c|c|}
\hline Source of Variance & Sum of Square & Df & Mean Square & F-cal & F-critical & Remarks \\
\hline Between Groups & 27.228 & 2 & 13.614 & & & \\
\hline Within Groups & 1121.655 & 83 & 13.514 & 1.007 & 3.11 & Not Significant \\
\hline Total & 1148.884 & 85 & & & & \\
\hline
\end{tabular}

The result in Table 6 indicated z-calculated value of .47 and z-critical value of 1.96 at 84 degrees of freedom and .05 level of significance. Since the calculated value of $\mathrm{z}$ is less than the critical value of $\mathrm{z}$, the null hypothesis is retained. This implies that location as a factor did not affect the Building Technology lecturers' mean ratings on the aspects cooperative learning model used in building technology instructional delivery.

Table 6: Z-test of difference on the Mean responses of Building Technology Lecturers in South-East and SouthSouth on the aspects cooperative learning model used in their instructional delivery

\begin{tabular}{|c|c|c|c|c|c|c|c|}
\hline Location & $\mathbf{N}$ & Mean & SD & Df & Z-cal & Z-critical & Remarks \\
\hline South-East & 23 & 4.36 & 1.87 & 84 & .47 & 1.96 & Not Significant \\
\hline South-South & 63 & 4.27 & 1.73 & & & & \\
\hline
\end{tabular}

The result in Table 7 revealed F-calculated value of .06 while F-critical is .99 with 2 and 83 degrees of freedom at .05 level of significance. Therefore, the null hypothesis is retained. This implies that Building Technology lectures in Federal, State and Private Polytechnics in South-East and South-South Nigeria do 
Sprouting employability skills in building technology students' using cooperative learning approaches in Nigerian Polytechnics

not differ significantly in their mean ratings on the employability skills that can be developed in building technology graduates utilizing cooperative learning approaches.

Table 7: Summary of Analysis of Variance on the responses of lecturers on the employability skills that can be developed in building technology graduates utilizing cooperative learning approaches

\begin{tabular}{|c|c|c|c|c|c|c|}
\hline Source of Variance & Sum of Square & Df & Mean Square & F-cal & F-critical & Remarks \\
\hline Between Groups & 2.09 & 2 & .52 & & & \\
\hline Within Groups & 1796.21 & 83 & 12.39 & .06 & .99 & Not Significant \\
\hline Total & 1798.29 & 85 & & & & \\
\hline
\end{tabular}

The result in Table 8 indicated z-calculated value of .65 and z-critical value of 1.96 at 84 degrees of freedom and .05 level of significance. Since the calculated value of $\mathrm{z}$ is less than the critical value of $\mathrm{z}$, the null hypothesis is retained. This implies that location as a factor did not affect the Building Technology lecturers' mean ratings on the employability skills that can be developed in building technology graduates utilizing cooperative learning approaches.

Table 8: Z-test of difference on the Mean responses of Building Technology Lecturers in South-East and South-South on the employability skills that can be developed in building technology graduates utilizing cooperative learning approaches

\begin{tabular}{|c|c|c|c|c|c|c|c|}
\hline Location & $\mathbf{N}$ & Mean & SD & Df & Z-cal & Z-critical & Remarks \\
\hline South-East & 23 & 4.61 & 1.88 & 84 & .65 & 1.96 & Not Significant \\
\hline South-South & 63 & 4.50 & 1.63 & & & & \\
\hline
\end{tabular}

\section{DISCUSSION OF FINDINGS}

The findings from this study showed that explorative, transformative and exploitative aspects of cooperative learning approaches are employed by building technology lecturers in polytechnics for instructional delivery. Explorative learning used in building instructional technology delivery included: guided inquiry, peer-to-peer learning, cooperative learning as well as participatory learning. None of the items in this cluster was rated below the criterion mean value of 3.00 and the cluster had a grand Mean of 4.19 indicating a remarkable extent of the practice. Also, the transformative learning utilized by building technology lecturers included: instructional delivery practices such as: real-life project workshops, problem-based discussions/debates, systematic reporting, routine work-visits and micro-exhibitions. All the items here had their Means above the criterion Mean of 3.00 and a grand Mean of 4.14 which means that building technology lecturers employ these aspects of cooperative learning in instructional delivery.

Exploitative learning had project-based learning, design-based learning, problem-based learning, programmed instructions and independent learning approaches. This cluster had all its Mean above 3.00 and a grand Mean of 4.01 indicating the extent the lecturers instruct learners' responsibility using independent learning model. However, the total responses reveal that these aspects are employed in the instructional delivery of building technology. This finding is in corroborates the assertion of Rotherham and Willingham (2010) that teachers know some instructional delivery practices that foster employability skills. In the same vein, Burke (2011) supporting active and participatory approaches in higher education posited that cooperative learning is useful for learners' who are more likely satisfied with better grades; teachers' who teach independence, responsibility, creativity etc, and for employers who desire that learners develop skills in teamwork.

The findings from this study also showed that building technology lecturers in Polytechnics in South-East and South-South agreed that employability skills could be developed in building technology students' using cooperative learning approaches. Employability skills such as: critical thinking, problemsolving, creativity, manipulative, teamwork, leadership management, information literacy, research, media literacy, technological literacy, communication, contextual learning, innovative, flexibility, adaptability, individual productivity and responsibility, analytical, evaluative, environmental literacy, and entrepreneurial and business skills. The findings of the study indicated mean values ranging from 3.66 to 4.04; and a grand Mean of 3.97, which are above the criterion Mean value of 3.00. This implies that the respondents agreed that all the employability skills could be developed in building technology students' 
using cooperative learning approaches. This finding is in line with other results such as that of the International Society for Technology in Education (ISTE) (2007), Partnership for $21^{\text {st }}$ Century Skills (2011), Oviawe, Ezeji and Uwameiye (2016) to ensure that graduates of collegiate institutions possess the set of skills sort after by employers, business men, politicians and the entire ever-dynamic workplace.

The result in Table 5 revealed F-calculated value of 1.007 while F-critical is 3.11 with 2 and 83 degrees of freedom at .05 level of significance. Therefore, the null hypothesis is retained. This implies that Building Technology lectures in Federal, State and Private Polytechnics in South-East and SouthSouth Nigeria rated these aspects of cooperative learning approaches as being utilized for building technology instructional delivery. The findings of the study, as shown in Table 6, indicated z-calculated value of .47 and $z$-critical value of 1.96 at 84 degrees of freedom and .05 level of significance. Since the calculated value of $z$ is less than the critical value of $z$, the null hypothesis is retained. This implies that location as a factor does not influence Building Technology lecturers' mean ratings on the aspects cooperative learning model used in building technology instructional delivery.

The result in Table 7 revealed F-calculated value of .06 while F-critical is .99 with 2 and 83 degrees of freedom at .05 level of significance. Therefore, the null hypothesis is retained. This implies that Building Technology lectures in Federal, State and Private Polytechnics in South-East and SouthSouth Nigeria do not differ significantly in their mean ratings on the employability skills that can be developed in building technology graduates utilizing cooperative learning approaches.

The findings of this study revealed that location as a factor did not affect Building Technology lecturers' mean ratings on the employability skills that can be developed in building technology graduates utilizing cooperative learning approaches. This implies that all the aspects of cooperative learning model (explorative learning, transformative learning and exploitative learning) could be developed in students of building technology when cooperative learning model is integrated with instructional delivery addressing helps the one-size-fits-all approach to instruction, identifying repertoire of teaching and learning for improving the quality of school graduates from tertiary institutions in South-South Nigeria. Although the finding of this study indicated that building technology lectures employ explorative, transformative and exploitative aspects of cooperative learning, yet the implication abounds for lecturers, students and institution administrators. For example, application without outcomes implies inefficiency and ineffectiveness on the side of the lecturers. The implication of this situation is seen in poor or nonassessment of the employability skills perceived to be developed using cooperative learning model.

Consequently, students graduate from school without the needed employability skills sought after by the workplace. Besides, chance inculcation of employability skills in building technology students shows inattentiveness of the lecturers and administrators of institutions similar to the demand of the present workplace. It also designates that conscious efforts should be made in teaching and learning to inculcate and assess the flexible and adaptive skills for self-reliance, employability and career furtherance of graduates of building technology.

\section{CONCLUSION AND RECOMMENDATIONS}

The findings of this study indicated that explorative, transformative and exploitative aspects of cooperative learning model are employed by building technology lecturers in the delivery of their instructions; and that employability skills can be developed in building technology students utilizing aspects of cooperative learning models. However, the observed poor manifestation of these work habits and character traits on the students' side negates the coherence of the lecturers. This implies that employability is neither taught explicitly nor assessed over factual retention, which may be partially attributed to the lack of a model to serve as a guide. Therefore, cooperative learning model must be kept as a guide and employed consciously to develop employability skills required by building technology students' for proper functionality in what lays ahead of them after school. Based on the findings of this study, the following recommendations were made:

1. Building technology should ensure that students' assessment is all-encompassing, not only on the acquisition of knowledge and technical skills but also a hub on the development and mastery of employability skills for functionality in the ever-dynamic and the global workplace.

2. Building technology lecturers should strongly and consciously imbibe exploratory learning, transformative learning and exploitative learning in their teaching. 
Sprouting employability skills in building technology students' using cooperative learning approaches in Nigerian Polytechnics

3. Students of Building technology should be taught from the beginning of their programme the meaning and need for employability skills using actual-life projects in order to enhance their cooperative intelligence.

\section{REFERENCES}

Ajuluchukwu, E.N. (2012). Assessment of minimum academic standards adopted by universities in South-East and South-South for undergraduate business education programmes. Unpublished M.Sc thesis, Department of Vocational Education, Nnamdi Azikiwe University, Awka.

Alashwal, A. M. \& Abdul-Rahman, H. (2014). Aspects of project learning in construction: A socio-technical model. Construction innovation: Information, Process, Management, 14(2), 229-244.

Burke, A. (2011). Group work: How to use groups effectively. The journal of effective teaching, 11(2), 87-95.

California Community Colleges (n.d). Basic skills as a foundation for student success in California Community Colleges - Part 1: Review of literature and effective practices. Retrieved on $4^{\text {th }}$ May, 2018 from: www.cccbsi.org/websites/basicskills/

Chamizo, J.A. (2013). A new definition of model and modelling in Chemistry teaching. Science and Education, 22(7), 1613-1632. Doi: 10.1007/S11191-011-09407-07

Federal Republic of Nigeria (2014). National policy on education. Lagos: NERDC.

Great School Partners (2016). $21^{\text {st }}$ century skills. Retrieved on $2^{\text {nd }}$ May, 2018 from: http://adglossary.org/21stcentury-skills/

International Society for Technology in Education (2007). National education standards for students. Washington, DC: ISTE. Retrieved on $2^{\text {nd }}$ May, 2018 from: www.iste.org/standards/nets-for-students.aspx.

Kaufman, K.J. (2014). Ways to $21^{\text {st }}$ century skills: Why students need them and ideas for practical implementation. Kappa Delta Pi Record, 49(2), 78-83.

Lai, E.R. (2011). Collaboration: A literature review. Research report, Pearson's publications in pdf format. Retrieved on $2^{\text {nd }}$ May, 2018 from: http://research.www.pearsonassessments.com/

Larson, L., Miller, T. \& Ribble, M. (2010). 5 considerations for digital age learners. Learning and leading with technology, 37(4), 12-15.

Lewin, A.Y., Peters, C. \& Massini, S. (2011). Micro foundations of internal and external absorptive capacity routines. Organization Science, 22(1), 81-98.

Manley, K. \& Chen, L.E. (2015). Collaborative learning model of infrastructure construction: A capacity perspective. Construction innovation, 15(3), 355-377.

Markova, D. \& McArthur, A. (2016). Collaborative intelligence: Thinking with people who think differently. Park City: Professional Thinking Partners. Retrieved on $2^{\text {nd }}$ May, 2018 from: www.cqthebook.com/thebook.

National Bureau of Statistics (2018). Labour force statistics volume I: Unemployment and underemployment report. $\begin{array}{lllll}\text { Retrieved on } & 20^{\text {th }} & \text { April, } & 2020 & \text { from }\end{array}$ https://www.proshareng.com/admin/upload/reports/12246Q32018unemploymentbyState-proshare.pdf

National Board for Technical Education (2007). Curriculum for Building Technology. Kaduna: NBTE Press.

National Board for Technical Education (2008). Revised curriculum for technical colleges and polytechnics. Kaduna: NBTE Press.

Oviawe, J.I., Ezeji, S.C.O.A., \& Uwameiye, R. (2016). Effects of cooperative learning on building technology students' acquisition of workplace skills. Indian Journal of Vocational Education 20 \& 21 (1), 77-88. Published by PSS Central Institute of Vocational Education (PSSCIVE), NCERT, Bhopal.

Oviawe, J.I. \& Uwameiye, R. (2020). Approaches for Developing Generic Skills in Building Technology Graduates for Global Competitiveness. Journal of vocational education studies, 11(1), In press.

Ngige, C. (2019). Nigeria's unemployment rate hits $33.5 \%$ by 2020. Premium Times, May 2. Retrieved from https://www.premiumtimesng.com/news/top-news/328137-nigerias-unemployment-rate-hits-33-5-percent-by-2020-minister.html

Rotherham, A.J. \& Willingham, D.T. (2010). $21^{\text {st }}$ century skills: Not new but a worthy challenge. American Educators, Spring.

Schleicher, A. (2012). Preparing teachers and developing school leaders for the $21^{\text {st }}$ century:Lessons from around the world. Paris, France: OECD 